\title{
The effect of Black Plastic Mulch on Growth, Production and Root Development of Chenin blanc Vines under dryland conditions
}

\author{
J. H. VAN DER WESTHUIZEN \\ Oenological and Viticultural Research Institute, Private Bag X5026, Stellenbosch 7600
}

\begin{abstract}
Studies have shown that black plastic used as a mulch at planting time under conditions of limited or no irrigation, greatly increased the growth of the vines. Although the exposed plastic film deteriorated within two years, the favourable effect persisted to the fifth year after planting, bringing the mulched vines to production a year earlier than the unmulched vines. The advantages of plastic mulch are conservation of soil moisture, more uniform soil temperatures, weed control and less soil compaction. These factors increase root and shoot growth, and improve both survival of the young vines and production. The durability of the plastic film was extended by covering it with a layer of soil, and thus a longer period of weed control was obtained.
\end{abstract}

\section{INTRODUCTION}

The application of some soil cover as a mulch has been tested for a wide range of annual and perennial agricultural crops. Polyethylene film, i.e. plastic mulch, has proved to be beneficial for vegetables (Clarkson \& Frazier, 1957; Emmert, 1957; Knavel \& Mohr, 1967; Jones, Jones \& Ezell, 1977), maize (Ashby \& Lea, 1974) and sub-tropical fruit (Bredell \& Barnard, 1973). The establishment of new vineyard plantings with the aid of a plastic soil cover has been reported on by Moore (1963) in the United States of America, and various workers experimented with it in the vine growing regions of Europe (Agulhon, 1968; Fader, 1972, 1974; Freytag, 1972; Steinberg \& Abel, 1974; Hillebrand, 1978). Its advantages have been listed as conservation of soil moisture, more uniform soil temperatures, less leaching of fertilizers, less soil compaction, weed control, increased growth and higher survival rate.

The sucessful and uniform establishment of new vineyard plantings may cause problems in both irrigated and dryland viticultural areas. Dryland cultivation of vineyard is practised on a large scale in South Africa, and it is especially in these areas where the establishment of new plantings is often carried out under conditions which are not as conducive to successful early growth as in the irrigation regions because the young vines have a shallow and limited root system during the first year after planting, and have also to compete with weeds for soil moisture. Even between irrigations in the irrigation areas, the surface layer becomes unduly dry as a result of high temperature and wind (high evapotranspiration). Consequently a large number of transplanted vines may die during the first growing season, and replanting cannot take place before the next season. Under normal dryland conditions the replanting of vines ranges between $5 \%$ and $10 \%$ during the first few years. On poor soils and/or under unfavourable climatic conditions this percentage may be much higher. The capital outlay required to bring a vineyard to the productive stage increases annually, and it is evident that the unproductive period from planting to full production should be kept as short as possible. Bearing these circumstances in mind, two experiments were conducted to evaluate a mulch of black polyethylene film in the planting row during the establishment period of a vineyard.

\section{MATERIALS AND METHODS}

Experiment A: The first experiment was initiated in 1972 and corducted over a five year period at the experimental farm of the Oenological Viticultural Research Institute near Stellenbosch in the winter rainfall region, with the cultivar Chenin blanc grafted on the rootstock 99R. Dormant grafted vines from a nursery were planted in a clay-loam soil with a $3,0 \times 1,5 \mathrm{~m}$ spacing. The top soil depth was uniformly shallow $(300 \mathrm{~mm})$ within the block, with an underlaying clay pan and was only shallow tilled prior to planting. At planting time (1-9-1972) the soil was still quite moist after the winter rains and no additional irrigation was applied during the course of the experiment. The total summer rainfall for the first growing season (September 1972 till March 1973) was $180 \mathrm{~mm}$. Four different planting techniques, which were mainly aimed at preserving the vine from desiccation prior to root formation, were included in combination with the two main treatments i.e. plastic mulch and no plastic mulch, and were as follows:

(a) An earth mound covering the scion which was cut back to two visual buds.

(b) Wax coating (grafting wax) of the scion of the dormant vine which was cut back to two buds.

(c) Leaving only one cane which was to be cut back to two buds after apical bud burst.

(d) Control vines of which the scion was cut back to two buds and without wax coating or soil mound.

The total of eight treatments consisted of 12 vines each and were replicated six times in a randomized block design. Immediately after planting the black plastic film, $1,0 \mathrm{~m}$ wide and $60 \mu \mathrm{m}$ (micron) thick, was placed over the vines in the row. Above each vine the plastic sheeting was slit and pressed down over the vine to just below the graft union to prevent the growth of scion roots. The plastic film was buried at the edges and left on the soil to deteriorate.

In order to evaluate the reaction of the vines as influenced by the different treatments, the shoot growth rate, cane and crop mass, as well as the root mass at different 
depths, were measured. The shoot growth rate $(\mathrm{cm} / \mathrm{month})$ was measured on a single cane on two randomly selected vines in each test row for the first three growing seasons after planting. Crop and cane masses were taken on all the test vines for the duration of the experiment. At the end of the first growing season the root mass of one randomly selected vine in each of the six replications of the mulched and unmulched treatments was determined. During the ensuing three seasons these measurements were made on three randomly selected vines in both main treatments. The vines were carefully and completely dug out, and all the roots within the depth zones of $0-400$ and $400-800 \mathrm{~mm}$ weighed.

Soil moisture content was determined gravimetrically in five localities at a depth of $300 \mathrm{~mm}$ in the mulched and unmulched treatments on a monthly basis throughout the first growing season. Soil temperatures were recorded continuously at a $250 \mathrm{~mm}$ depth underneath the plastic film as well as in the unmulched treatments.

Experiment B: After planting in 1973, the effect of a $30 \mathrm{~mm}$ soil layer on the plastic cover in the row was also investigated in a separate, less extensive trial, with the same cultivar under similar experimental conditions for four successive seasons. Four treatments were applied:

(a) Plastic mulch covered with $30 \mathrm{~mm}$ of soil.

(b) Perforated plastic mulch, covered with $30 \mathrm{~mm}$ of soil.

(c) Non-covered plastic mulch.

(d) Control i.e. without any mulching.

A randomized block design with three replicates of five vines each, was used. Only cane and crop masses were determined during the course of the experiment.

In both experiments the vines were left untrellised and were spur pruned by experienced pruners according to the vigour of the vines.

\section{RESULTS AND DISCUSSION}

Experiment A: From the start of the first growing season it was evident that there were no distinct differences in percentage take or growth vigour between the four sub-treatments aimed at preserving the young dormant vine from desiccation. Table 1 gives the cane masses of these four treatments on the mulched and unmulched vines at the end of the first growing season. Statistical analysis of the data obtained in the second and third year after planting confirmed these results, and also indicated that there were no interactive effects between main and sub-treatments. Subsequently the evaluation of the results were made only on the two main treatments, i.e. mulched and unmulched vines.

Shoot Growth Already during the first growing season marked differences were observed in the rates of growth between the vines established with and without the plastic mulch (Fig. 1). During early and midsummer the growth rate of the mulched vines was about ten times greater than that of the unmulched vines. Towards the end of the season the shoots of the mulched vines were about four times longer than those of the unmulched vines. These observations were substantiated by the cane masses obtained at the end of the first growing season (Table 2). In comparison with unmulched vines those with plastic mulch gave a ninefold increase in cane mass. During the first season only $1,8 \%$ of the mulched vines did not take, whereas the corresponding figure in the unmulched treatments was nearly triple this value viz. $5,0 \%$. These pronounced improvements in growth during the first growing season can be attributed mainly to the more favourable soil moisture regime (Fig. 2) and apparently to a lesser extent to the prevailing soil temperature under the plastic cover

TABLE 1

Influence of plastic mulch and diferent planting techniques on the cane mass of non-irrigated Chenin blanc vines after the first growing season (1973/74)

\begin{tabular}{|c|c|c|c|c|}
\hline Treatments & $\begin{array}{l}\text { Plastic mulch } \\
\text { Cane mass } \\
\text { (g/vine) }\end{array}$ & $\begin{array}{l}\text { No plastic mulch } \\
\text { Cane mass } \\
\text { (g/vine) }\end{array}$ & $\begin{array}{l}\text { Mean cane mass } \\
(\mathrm{g} / \mathrm{vine})\end{array}$ & $\begin{array}{c}\text { Statistical } \\
\text { significance } \\
\text { of sub-treatment }\end{array}$ \\
\hline $\begin{array}{l}\text { (a) Earth mound covering aerial part of vine which was } \\
\text { cut back to two buds. } \\
\text { (b) Wax coating of scion part of vine which was cut } \\
\text { back to two buds. } \\
\text { (c) Leaving one long cane on vine which was cut back } \\
\text { to two buds after budding. } \\
\text { (d) Control-aerial part was cut back to two buds. }\end{array}$ & $\begin{array}{l}27,9 \\
23,7 \\
30,8 \\
29,6\end{array}$ & $\begin{array}{l}4,0 \\
1,9 \\
3,3 \\
2,2\end{array}$ & $\begin{array}{l}16,0 \\
12,8 \\
17,1 \\
15,1\end{array}$ & $\begin{array}{l}\text { N.S. } \\
\text { N.S. } \\
\text { N.S. } \\
\text { N.S. }\end{array}$ \\
\hline $\begin{array}{l}\text { Mean shoot mass } \ldots \ldots \ldots \ldots \ldots \ldots \ldots \ldots \ldots \ldots \ldots \ldots \\
\text { Significance of main treatments } \ldots \ldots \ldots \ldots \ldots \ldots \ldots\end{array}$ & D-value $(P=0,05)$ & $\begin{array}{l}2,9 \\
9,3\end{array}$ & & \\
\hline
\end{tabular}

TABLE 2

Effect of black plastic mulch on the cane and crop masses of non-irrigated Chenin blanc vines during the first five years after planting (1972)

\begin{tabular}{|c|c|c|c|c|c|c|c|}
\hline \multirow{2}{*}{\multicolumn{2}{|c|}{ Season }} & \multicolumn{3}{|c|}{ Cane mass (g/vine) } & \multicolumn{3}{|c|}{ Crop mass at $20^{\circ}$ Balling (g/vine) } \\
\hline & & Plastic mulch & No plastic mulch & $\begin{array}{c}\text { L.S.D. } \\
(P=0,05)\end{array}$ & Plastic mulch & No plastic mulch & $\begin{array}{c}\text { L.S.D. } \\
(\mathrm{P}=0,05)\end{array}$ \\
\hline $\begin{array}{l}\text { First } \\
\text { Second } \\
\text { Third } \\
\text { Fourth } \\
\text { Fifth }\end{array}$ & 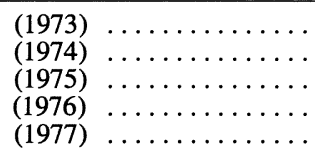 & $\begin{array}{r}28,0 \\
158,0 \\
398,9 \\
491,0 \\
645,0\end{array}$ & $\begin{array}{r}2,9 \\
41,0 \\
145,9 \\
267,6 \\
452,5\end{array}$ & $\begin{array}{r}9,3 \\
35,8 \\
89,2 \\
96,4 \\
170,0\end{array}$ & $\begin{array}{r}\text { No crop } \\
155,8 \\
653,0 \\
1872,5 \\
957,5\end{array}$ & $\begin{array}{r}\text { No crop } \\
1,9 \\
195,3 \\
1087,5 \\
870,0\end{array}$ & $\begin{array}{l}-\overline{109,1} \\
261,2 \\
460,0 \\
\text { N.S. }\end{array}$ \\
\hline
\end{tabular}

$1 \mathrm{~g} / \mathrm{vine}=2,222 \mathrm{~kg} / \mathrm{ha}$ 


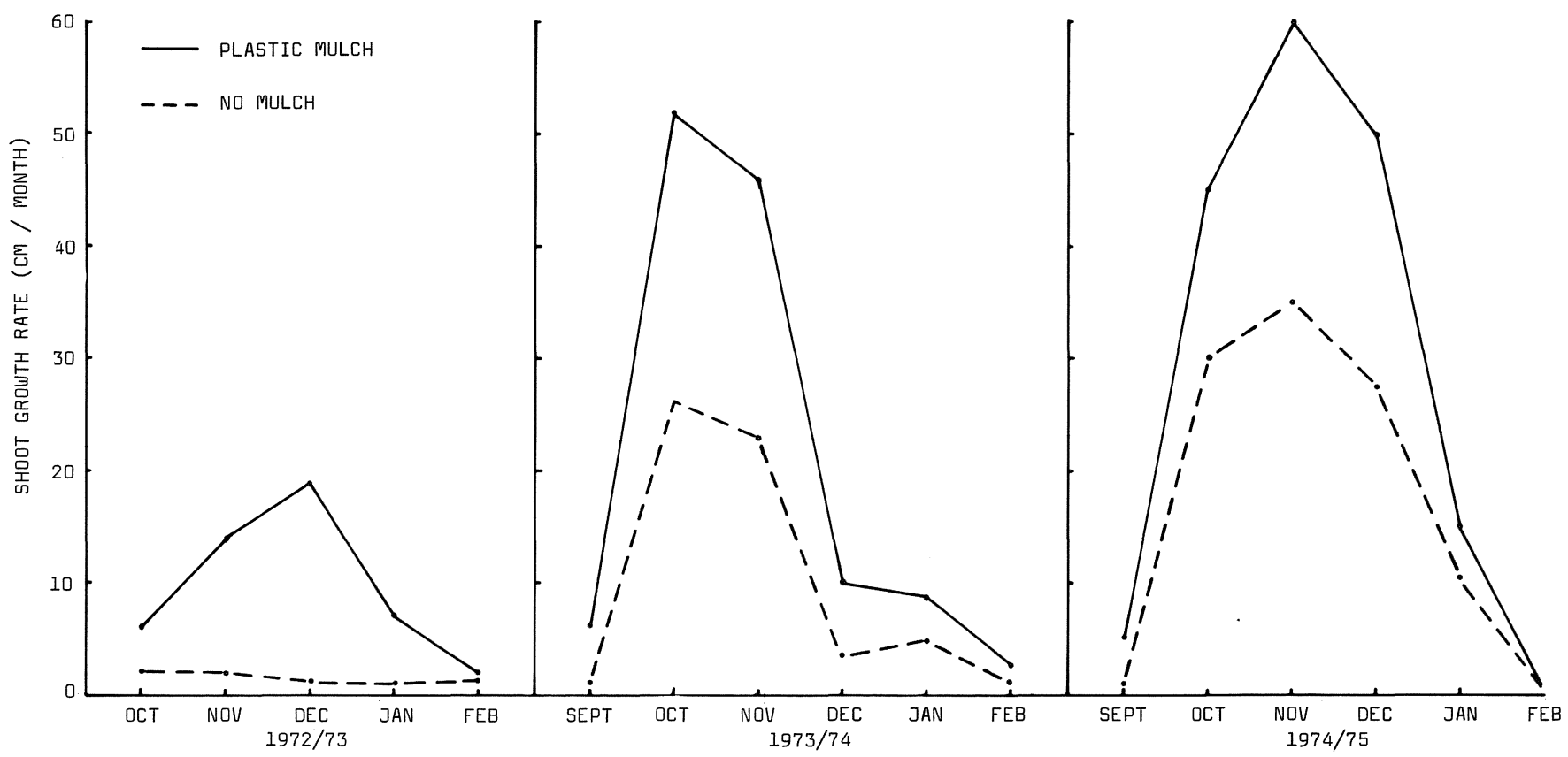

FIG. 1

Influence of plastic mulch on rate of shoot growth for three successive seasons after planting in 1972.

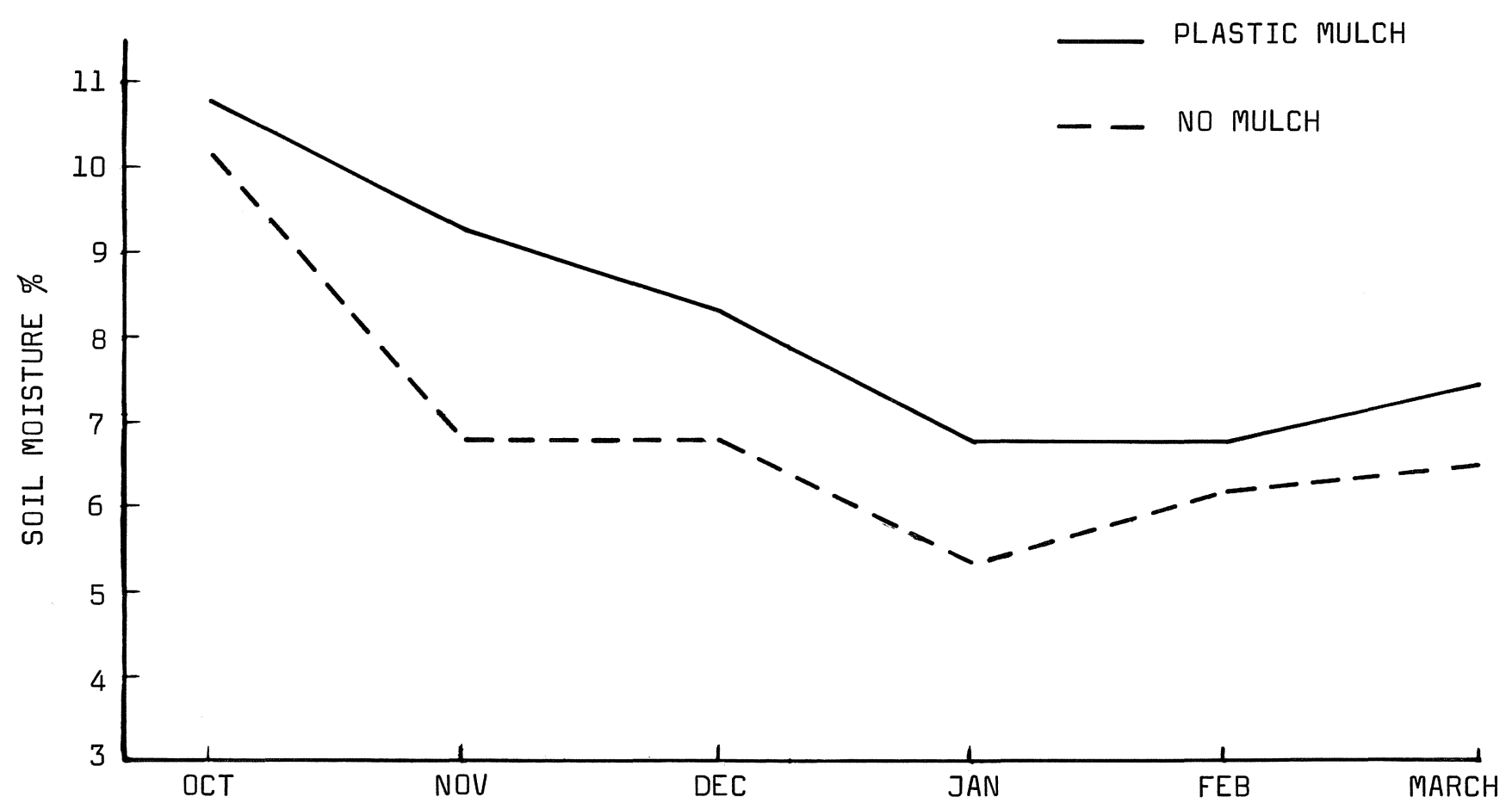

Fig. 2

Influence of plastic mulch on soil moisture content at $300 \mathrm{~mm}$ depth during the first growing season (1972/73).

(Fig. 3). At a soil depth of $300 \mathrm{~mm}$ the moisture content under the plastic cover exceeded that in the unmulched soil by an average of $28 \%$ (2,0\% soil moisture) in November and December. This period also coincided with the period of the highest rate of shoot growth in the mulched treatments.

At a depth of $250 \mathrm{~mm}$ no significant differences were found between the average temperature of mulched and unmulched soil. It was, however, evident that the black plastic cover has a stabilizing effect on the temperature of the soil. A more constant temperature was maintained under the plastic mulch. In the mulched soil the average minimum temperature was about $1,7{ }^{\circ} \mathrm{C}$ higher and the average maximum temperature about $1,5^{\circ} \mathrm{C}$ lower than the corresponding temperatures in the unmulched soil (Fig. 3). During January and February maximum soil temperatures as high as 32 and $33{ }^{\circ} \mathrm{C}$ were reached in the unmulched soil, compared with 29,5 and $30,5^{\circ} \mathrm{C}$ in the mulched soil. Various workers have shown that black plastic tends to stabilize temperature by causing increases in minimum and 


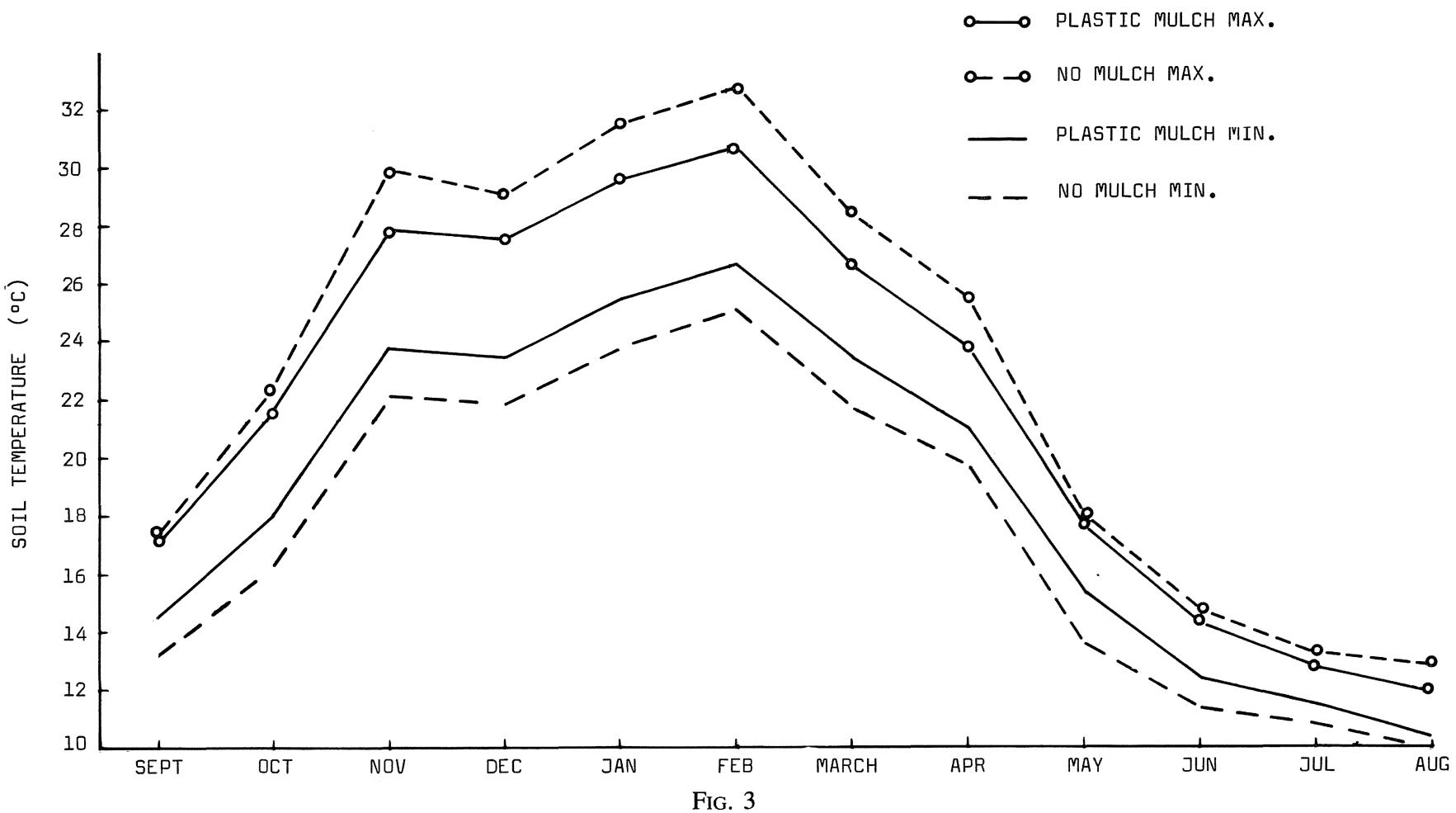

Average monthly maximum and minimum soil temperatures at $250 \mathrm{~mm}$ depth with and without plastic mulch during the first growing season $(1972 / 73)$.

decreases in maximum temperatures (Moore, 1963; Agulhon, 1968; Bredell \& Barnard, 1973).

In spite of the decomposition of the plastic film after approximately eighteen months, the vines maintained their strong rate of growth during the second and third seasons (Fig. 1). During the active growing period of these two seasons the growth rate of the mulched vines was approximately twice that of the unmulched vines, whereas the cane mass at the end of the season was more than three times higher (Table 2). The higher cane mass obtained in the fourth and fifth seasons after planting clearly demonstrates the prolonged beneficial effect of the plastic mulch in comparison with the unmulched vines (Table 2). Similarly the cane mass of the mulched vines was 83 and $42 \%$ higher than that of the unmulched vines for the fourth and fifth seasons respectively.

Crop Mass The crop mass obtained from the second season showed similar differences between the two treatments (Table 2). As the vines established without a plastic mulch developed so poorly under the unfavourable dryland conditions, they produced practically no grapes, viz. 1,9 $\mathrm{g} / \mathrm{vine}(4,2 \mathrm{~kg} / \mathrm{ha})$, during the second season, whereas the mulched vines produced 155,8 $\mathrm{g} / \mathrm{vine}(346,2 \mathrm{~kg} / \mathrm{ha})$.
Yields of 635,0 and $1872,5 \mathrm{~g} / \mathrm{vine}(1411,0$ and 4160,7 $\mathrm{kg} / \mathrm{ha}$ ) were obtained during the third and fourth seasons respectively from the mulched vines, whereas the unmulched vines produced only 195,3 and $1087,5 \mathrm{~g} /$ vine (434,0 and $2416,4 \mathrm{~kg} / \mathrm{ha}$ ) respectively during the corresponding periods. In the fifth season, however, no statistical difference in crop mass was observed. This could possibly be ascribed to the abnormally high summer rainfall leading to a serious downy mildew infection and a $38 \%$ overall crop loss, especially severe in the more vigorous mulched vines.

Root Growth The development of the vine roots as influenced by the plastic mulch was investigcted during the first four years after planting, and the relevant data are given in Table 3. At the end of the first season the rootmass under the plastic cover was more than three times higher than that of the unmulched vines. Although the plastic film had already disintegrated after 18 months, these vines maintained their supremacy during the succeeding years with respect to both shallow and deeper roots. After the third and fourth seasons, the total root mass was respectively 65,9 and $92,7 \%$ greater than that of the unmulched vines.

TABLE 3

Root masses of vines established with and without black plastic mulch measured at various depths for four successive seasons after planting (1972)

\begin{tabular}{|c|c|c|c|c|c|c|c|c|c|c|}
\hline \multirow{2}{*}{\multicolumn{2}{|c|}{ Season }} & \multicolumn{3}{|c|}{$\begin{array}{l}\text { Root mass at } 0-400 \mathrm{~mm} \\
\text { soil depth }(\mathrm{g} / \mathrm{vine})\end{array}$} & \multicolumn{3}{|c|}{$\begin{array}{l}\text { Root mass at } 400-800 \mathrm{~nm} \\
\text { soil depth (g/vine) }\end{array}$} & \multicolumn{3}{|c|}{$\begin{array}{l}\text { Total root mass } \\
\text { (g/vine) }\end{array}$} \\
\hline & & $\begin{array}{l}\text { Plastic } \\
\text { mulch }\end{array}$ & $\begin{array}{l}\text { No plastic } \\
\text { mulch }\end{array}$ & $\begin{array}{c}\text { L.S.D. } \\
(\mathrm{P}=0,05)\end{array}$ & $\begin{array}{l}\text { Plastic } \\
\text { mulch }\end{array}$ & $\begin{array}{l}\text { No plastic } \\
\text { mulch }\end{array}$ & $\begin{array}{c}\text { L.S.D. } \\
(\mathrm{P}=0,05)\end{array}$ & $\begin{array}{l}\text { Plastic } \\
\text { mulch }\end{array}$ & $\begin{array}{l}\text { No plastic } \\
\text { mulch }\end{array}$ & $\begin{array}{c}\text { L.S.D. } \\
(\mathrm{P}=0,05)\end{array}$ \\
\hline $\begin{array}{l}\text { First } \\
\text { Second } \\
\text { Third } \\
\text { Fourth }\end{array}$ & $\begin{array}{c}(1973) \ldots \ldots \\
(1974) \ldots \ldots \\
(1975) \ldots \ldots \\
(1976) \ldots \ldots\end{array}$ & $\begin{array}{r}79,8 \\
127,6 \\
218,7 \\
442,0\end{array}$ & $\begin{array}{r}25,8 \\
79,4 \\
120,7 \\
225,3\end{array}$ & $\begin{array}{l}41,7 \\
\text { N.S. } \\
\text { N.S. } \\
121,6\end{array}$ & $\begin{array}{l}0 \\
31,8 \\
184,0 \\
252,0\end{array}$ & $\begin{array}{r}0 \\
9,7 \\
122,0 \\
134,7\end{array}$ & $\begin{array}{l}-\overline{10} \\
\text { N.S. } \\
95,4\end{array}$ & $\begin{array}{r}79,8 \\
159,4 \\
402,7 \\
694,0\end{array}$ & $\begin{array}{r}25,8 \\
89,1 \\
242,7 \\
360,0\end{array}$ & $\begin{array}{c}41,7 \\
\text { N.S. } \\
44,4 \\
190,2\end{array}$ \\
\hline
\end{tabular}


TABLE 4

The effect of covering of the plastic mulch with a layer of soil ( $30 \mathrm{~mm}$ thick) on the cane and crop masses of non-irrigated Chenin blanc vines during the first four years after planting (1973)

\begin{tabular}{|c|c|c|c|c|c|c|c|c|c|c|}
\hline \multirow[b]{2}{*}{ Season } & & \multicolumn{4}{|c|}{ Cane mass (g/vine) } & \multicolumn{5}{|c|}{ Crop mass at $20^{\circ}$ Balling (g/vine) } \\
\hline & $\begin{array}{l}\text { Soil- } \\
\text { covered } \\
\text { plastic } \\
\text { mulch }\end{array}$ & $\begin{array}{l}\text { Soil- } \\
\text { covered } \\
\text { perfora- } \\
\text { ted plas- } \\
\text { tic mulch }\end{array}$ & $\begin{array}{l}\text { Non- } \\
\text { covered } \\
\text { plastic } \\
\text { mulch }\end{array}$ & $\begin{array}{l}\text { No } \\
\text { plastic } \\
\text { mulch }\end{array}$ & $\begin{array}{c}\text { D-value } \\
(P=0,05)\end{array}$ & $\begin{array}{l}\text { Soil- } \\
\text { covered } \\
\text { plastic } \\
\text { mulch }\end{array}$ & $\begin{array}{l}\text { Soil- } \\
\text { covered } \\
\text { perfora- } \\
\text { ted plas- } \\
\text { tic mulch }\end{array}$ & $\begin{array}{l}\text { Non- } \\
\text { covered } \\
\text { plastic } \\
\text { mulch }\end{array}$ & $\begin{array}{l}\text { No } \\
\text { plastic } \\
\text { mulch }\end{array}$ & $\begin{array}{c}\text { D-value } \\
(\mathrm{P}=0,05)\end{array}$ \\
\hline $\begin{array}{ll}\text { First } & (1974) \ldots \\
\text { Second } & (1975) \ldots \\
\text { Third } & (1976) \ldots \\
\text { Fourth } & (1977) \ldots\end{array}$ & $\begin{array}{r}15,1 \\
200,0 \\
340,0 \\
560,0\end{array}$ & $\begin{array}{r}11,3 \\
223,3 \\
272,5 \\
673,3\end{array}$ & $\begin{array}{r}28,7 \\
273,3 \\
360,0 \\
666,6\end{array}$ & $\begin{array}{r}2,0 \\
38,7 \\
140,0 \\
256,6\end{array}$ & $\begin{array}{r}13,4 \\
152,0 \\
170,0 \\
240,0\end{array}$ & $\begin{array}{r}\text { No crop } \\
123,3 \\
1720,0 \\
1453,3\end{array}$ & $\begin{array}{c}\text { No crop } \\
91,7 \\
1600,0 \\
1360,0\end{array}$ & $\begin{array}{r}\text { No crop } \\
438,3 \\
1360,0 \\
1373,3\end{array}$ & $\begin{array}{r}\text { No crop } \\
8,3 \\
720,0 \\
1233,3\end{array}$ & $\begin{array}{l}\overline{356,4} \\
480,0 \\
\text { N.S. }\end{array}$ \\
\hline
\end{tabular}

Experiment B: The results of the effect of a layer of soil on the plastic cover in the row on the establishment of a new vineyard are given in Table 4. No significant differences occurred between the soil-covered, perforated or non-perforated plastic mulch treatments during the course of the experiment.

In comparison with the non-covered plastic sheeting, the average cane mass of the vines established under soilcovered plastic sheeting (perforated and non-perforated) was, after the first season, about 54\% lower, but still almost seven times higher than that of the vines established without any mulch. Because the uncovered plastic sheeting already started to disintegrate during the second season, whilst the soil covered sheeting was still effective as regards moisture retention, this difference in growth was eliminated during the succeeding seasons. The greater cane mass initially obtained in the non-covered plastic treatment could probably be ascribed to a more favourable soil temperature i.e. a more stable temperature. In the third season the yield and cane mass of the vines established under soil-covered sheeting were more or less the same as that of the vines established under non-covered plastic sheeting and more than twice as high as that of the vines established without any cover. Although the average cane mass of the soil-covered plastic mulch treatments was almost 2,5 times as high as the non-mulched treatments, there were as in the case of Experiment $A$ again no significant differences in crop mass during the fifth (1976/ 77) season. In comparison with the non-covered plastic sheeting, the soil covered plastic sheeting remained intact for three seasons and formed an excellent aid in the control of weeds.

\section{CONCLUSION}

The application of black polyethylene film as a mulch in the row during the establishment period of vines, especially where soil moisture conditions are a limiting factor, undoubtedly promotes the development of the young vines, bringing them into bearing at least one year earlier. This advantageous effect was observed until the fifth year after planting.

Results obtained in this investigation are in agreement with those reported on by various workers in different countries (Moore, 1963; Agulhon, 1968; Fader, 1972, 1974; Steinberg \& Abel, 1974; Hillebrand, 1978). The main factors responsible for the increased growth of the mulched vines may in all probability be attributed to the improvement of the physical soil condition underneath the plastic sheeting as indicated by Moore (1963), Agulhon
(1968), Fader (1974) and Hillebrand (1978). Conservation of soil moisture takes place through the reduction of evaporation from the soil. Loss of water is further restricted by the control of weeds in the immediate vicinity of the vine where the roots are mainly to be found during the first season. Thus the vines will have less competition from weeds for nutrients and soil moisture. It is reported that plastic mulch reduces loss of nitrogen by leaching (Bredell \& Barnard, 1973; Jones et al, 1977). Due to the elimination of the detrimental effects of sun, rain and mechanical compaction, a soil with a better physical structure is also obtained under the plastic cover (Bredell \& Barnard, 1973; Hillebrand, 1978). A milder or more stabilized temperature is also obtained under the plastic sheeting. All these beneficial effects give rise to a better root development, viz. threefold that of the unmulched vines during the first year after planting.

The stronger top growth during the first two years after planting will enable producers to bring vines to trellis at a considerably earlier stage than would be the case with unmulched vines (Hillebrand, 1978). The higher percentage take obtained with plastic mulching, minimises the cost of replanting of vines, whilst the damaging of young vines during clean ridge cultivation practice is also eliminated.

Calculations made on the current fixed price for wine grapes showed that over the first three years after planting the mulched vines, in comparison with the unmulched vines, have a cumulative financial gain which was appreciably more than the higher investment cost of the plastic mulch (Van der Westhuizen, 1977). A similar cost evaluation over the first three years after planting, made by Hillebrand (1978) and Fader (1974) in West Germany between mulched and unmulched vines, revealed no difference in cost. Covering the plastic sheeting with a layer of soil, will keep the weeds under control for a longer period, resulting in an appreciable saving in labour costs.

\section{LITERATURE CITED}

AGULHON, R., 1968. Paillage plastique á la plantation des vignes. Vignes Vins 171, 9-22.

ASHBY, E. S. \& LEA, J. D., 1974. Effect of polyethylene and grass mulches on soil temperature and germination of maize in Devon soil. Crop Production 3, 33-36.

BREDELL, G. S. \& BARNARD, C. J., 1973. Reaksie van sommige subtropiese vrugtesoorte op plastiek en ander soorte deklae. Crop Production 2, 15-19.

CLARKSON, V. A. \& FRAZIER, W. A., 1957. Effect of paper and polyethylene mulches and caps on cantaloupe yields and earliness. Proc. Am. Soc. hort. Sci. 69, 400-404. 
EMMERT, F. M., 1957. Black polyethylene for mulching vegetables. Proc. Am. Soc. hort. Sci. 69, 464-469.

FADER, W., 1972. Anwendung von Folien zur Bodenbedeckung in Neuanlagen. Dte Weinb. 28, 262-266.

FADER, W., 1974. Mulchfolie in Rebenjunganlagen. Weinberg Keller 21, 183-191.

FREYTAG, G., 1972. Anwendung von Kunststoffolien im Weinbau (Seilzulagen). Dte Weinb. 28, 266-268.

HILLEBRAND, W., 1978. Anwendung von Mulchfolien in Rebenneuanlagen. Rebe \& Wein 31, 60-61.

JONES, T. L., JONES, U. S. \& EZELL, D. O., 1977. Effect of nitrogen and plastic mulch on properties of Troup loamy sand and on yield of Walter tomatoes. J. Am. Soc. hort. Sci. $102,273-275$.

KNAVEL, D. E. \& MOHR, H. C., 1967. Distribution of roots of four different vegetables under paper and polyethylene mulches. Proc. Am. Soc. hort. Sci. 91, 589-597.

MOORE, R. C., 1963. Plastic mulch aids growth of young grape vines and cuttings. Biokemia 1/1, 21-23.

STEINBERG, B. \& ABEL, E., 1974. Die Anwendung von Mulchfolien in Junganlagen. Weinberg Keller 21, 121-143.

VAN DER WESTHUIZEN, J. H., 1977. The establishment of vineyard with the aid of a plastic soil cover. Farming in South Africa, Oenological and Viticultural Series No. D4/ 1977. 